\title{
Synthesis, Complexation, Spectral and Antimicrobial Study of Some Novel 5-Bromo-2- Fluorobenzaldehydeoxime
}

\author{
K. Kumar, N. Santhi* \\ Department of Chemistry, Government Arts College, Chidambaram-608201, Tamil Nadu, India \\ *E-mail address: nsaanthi@gmail.com
}

\begin{abstract}
In this newly approached method a novel series of Transition metal complexes were synthesized by the reaction of 5-bromo-2-fluorobenzaldehyde (1) react with hydroxylamine in ethanolic solution at room temperature. Mononuclear complexes were synthesized by reaction with $\mathrm{Cu}(\mathrm{II}), \mathrm{Zn}(\mathrm{II})$ and $\mathrm{Hg}(\mathrm{II})$ chloride salts. The complexes were characterized by elemental analysis, Ultraviolet, Infra -red and ${ }^{1}$ HNMR spectral studies. The antimicrobial activities of the ligand and its metal complexes were estimated.
\end{abstract}

Keywords: Substituted benzaldehyde; metals; complexes; antibacterial and antifungal activity

\section{INTRODUCTION}

In recent years, the chemistry of coordination compounds has shown rapid development in diverse disciplines as a result of possible use of these new compounds in biological applications. Transition metal complexes with potential biological activity are the main focus of extensive investigation. The biological importance of oximes and their complexes is very well known. Metal complexes with ligands containing nitrogen and oxygen donor atoms have act as the fungicidal agents.

Synthesis of oximes, and their complexes with different transition metals are reported in the literature ${ }^{1-9}$ and found to be active as antibacterial , antitubercular ${ }^{8}$, antilepral ${ }^{10}$, antiviral $^{11}$, antimalarial ${ }^{12}$ and active against certain kinds of tumours ${ }^{13,14}$. In this paper, a novel series of transition metal complexes with oxime were synthesized and they were screened for antimicrobial activities. Most of the complexes were shown moderate to good antibacterial and antifungal activity.

\section{EXPERIMENTAL METHODS}

The chemicals such as 5-bromo-2-fluorobenzaldahyde, cobalt chloride, Mercury chloride and Zinc chloride were procured from Sigma-Aldrich Chem, Bangalore. Melting 
points were observed in open capillaries and were uncorrected. IR spectra of all compounds were recorded in Perkin-Elmer 883 spectrometer using $\mathrm{KBr}$ pellets. The antibacterial and antifungal activities of all compounds were observed using cup-plate method ${ }^{11}$.

\section{RESULTS AND DISCUSSION}

General method for synthesis of 5-bromo-2-fluorobenzaldehyde oxime (1)

A mixture of 5-bromo-2-fluorobenzaldehyde $(0.02 \mathrm{~mol})$ in $15 \mathrm{~mL}$ ethanol was added to aqueous solution of hydroxylamine hydrochloride $(0.08 \mathrm{~mol})$ and sodium acetate $(0.1 \mathrm{~mol})$.

This mixture was stirred continuously for 10 minutes at room temperature and then allowed to cool. The precipitated compound 5-bromo-2-fluorobenzaldehydeoxime was collected and purified by crystallization method using ethanol (yield: $84.3 \%$ ).

General method for synthesis of Complexes of 5-bromo-2-fluorobenzaldehydeoxime with $\mathrm{Co}(I I), \mathrm{Hg}(I I)$ and $\mathrm{Zn}(I I)$.

5-bromo-2-fluorobenzaldehydeoxime $(0.002 \mathrm{~mol})$ was dissolved in $15 \mathrm{~mL}$ ethanol and was added to dissolved cobalt, nickel and copper chloride $(0.001 \mathrm{~mol})$ in $15 \mathrm{~mL}$ ethanol. The mixture was heated at $60^{\circ} \mathrm{C}$ for $2 \mathrm{~h}$ and then left to cool.

The precipitate was collected and purified by crystallization from ethanol to give compounds as crystals, yields, 73.1, 65.7 and $80.1 \%$ respectively.

SCHEME : I<smiles>O=Cc1cc(Br)ccc1F</smiles><smiles>O=Cc1cc(Br)ccc1F</smiles> 

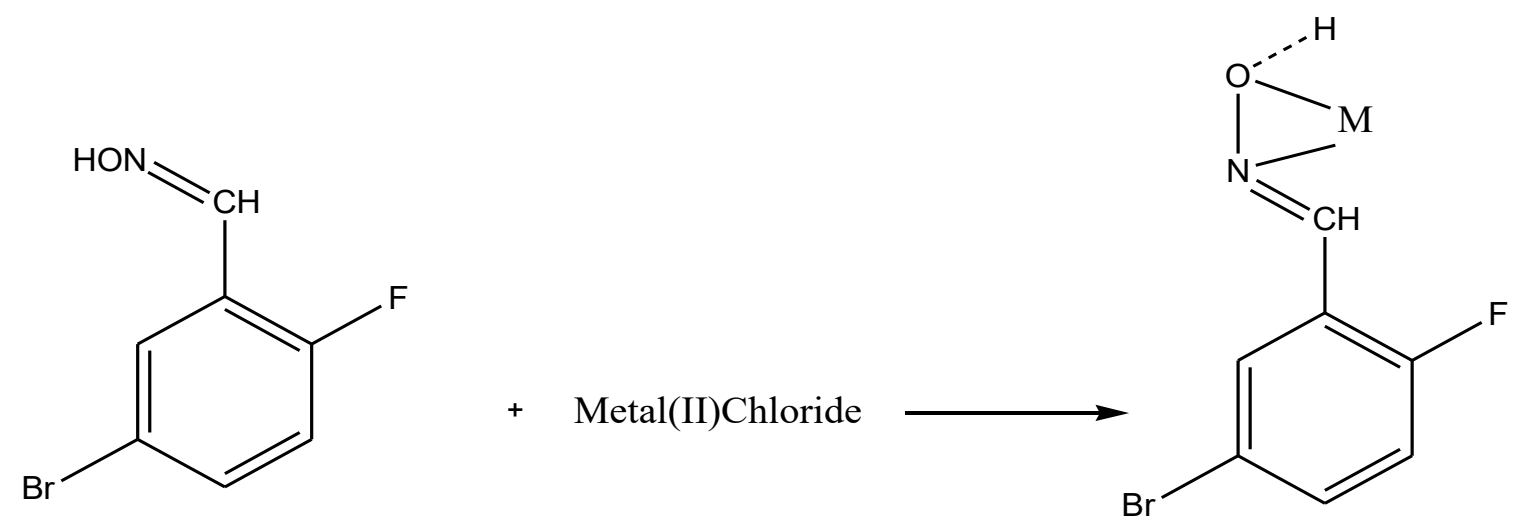

$M=C u(I I), Z n(I I)$ and $H g(I I)$

Table 1. Physical and analytical data of complexes

\begin{tabular}{|c|c|c|c|c|c|}
\hline \multirow{2}{*}{ Compounds } & \multirow{2}{*}{ Color } & \multirow{2}{*}{ M. P $\left({ }^{\circ} \mathbf{C}\right)$} & \multicolumn{3}{|c|}{ Elemental analysis (found) \% } \\
\hline & & & $\mathbf{C}$ & $\mathbf{H}$ & $\mathbf{N}$ \\
\hline Ligand & White & $82-86$ & $\begin{array}{l}35.50 \% \\
(35.68)\end{array}$ & $\begin{array}{l}2.0 \% \\
(2.98)\end{array}$ & $\begin{array}{l}6.15 \% \\
(6.56)\end{array}$ \\
\hline $\mathrm{Cu}(\mathrm{II})$ & Pale green & $108-112$ & $\begin{array}{c}29.24 \\
(29.30)\end{array}$ & $\begin{array}{c}1.86 \\
(1.94)\end{array}$ & $\begin{array}{r}5.98 \\
(6.02)\end{array}$ \\
\hline $\mathrm{Zn}(\mathrm{II})$ & White & $>250$ & $\begin{array}{c}29.38 \\
(29.44)\end{array}$ & $\begin{array}{c}1.90 \\
(1.96)\end{array}$ & $\begin{array}{r}5.46 \\
(5.54)\end{array}$ \\
\hline $\mathrm{Hg}(\mathrm{II})$ & Pale white & $>250$ & $\begin{array}{l}29.52 \\
(29.60)\end{array}$ & $\begin{array}{c}1.81 \\
(1.89)\end{array}$ & $\begin{array}{r}5.77 \\
(5.82)\end{array}$ \\
\hline
\end{tabular}

Table 2. The electronic spectra of all the complexes were recorded in ethanol

\begin{tabular}{|c|l|c|}
\hline S. No & Compound name & $\lambda_{\max }$ \\
\hline 1 & Ligand & 310,297 and $250 \mathrm{~nm}$ \\
\hline 2 & Co(II) complexe & 211 to 249,297 to 307 and 326 to 588 \\
\hline 3 & Zn(II) complexe & 212 to 251,297 to 307 \\
\hline 4 & Hg(II) complexes & 250 to 297,307 to 517 \\
\hline
\end{tabular}


From the spectra of free ligand, $\pi \rightarrow \pi^{*}$ transitions were obtained. Then $\rightarrow \pi^{*}$ transitions were also associated with nitrogen of the azomethine and oxime group in the free ligand. In the complexes, the $\mathrm{n} \rightarrow \pi^{*}$ transition was shifted to higher energy level. These results were indicated that the nitrogen and /or oxygen atom of the oxime groups were coordinated to the metal ions. These bands were assigned to both a charge transfer transition from the metal to anti-bonding orbital of the ligand and to spin allowed transition of the ligand. The observed absorptions of ligand such as 310, 297 and $250 \mathrm{~nm}$ were assigned to the $\mathrm{n} \rightarrow \pi^{*}$ and $\pi \rightarrow \pi^{*}$ transitions ${ }^{15}$.

Table 3. IR spectra

\begin{tabular}{|c|c|c|c|c|c|}
\hline Compounds & $v(\mathbf{O}-\mathbf{H})$ & $v(\mathbf{C}=\mathbf{N})$ & $v(\mathbf{N}-\mathbf{O})$ & $v(\mathbf{N}-\mathbf{M})$ & $v(\mathbf{M}-\mathbf{O})$ \\
\hline Ligand & 3294 & 1633 & 972 & - & - \\
\hline $\mathrm{Cu}(\mathrm{II})$ & - & 1593 & 975 & 464 & 526 \\
\hline $\mathrm{Zn}(\mathrm{II})$ & - & 1591 & 974 & 462 & 526 \\
\hline $\mathrm{Hg}(\mathrm{II})$ & 3522 & 1614 & 970 & 460 & 524 \\
\hline
\end{tabular}

The infrared spectra of free ligand shown broad band at $3294 \mathrm{~cm}^{-1}$ which correspond to $-\mathrm{OH}$ group of oxime. The IR frequency of all the complexes were shifted to lower frequencies for $-\mathrm{OH}$ of oxime. This may be due to formation of coordinate covalent bond through oxygen atom of hydroxyl group to metal. The IR frequency at $1633 \mathrm{~cm}^{-1}$ had indicated the existence of $-\mathrm{C}=\mathrm{N}$ group. The IR spectra of all the $-\mathrm{C}=\mathrm{N}$ group of azomethine had also shifted to lower frequencies and it was shown the existence of coordinate bond formation with metals through nitrogen atom of azomethine group ${ }^{15}$.

\section{SPECTRAL STUDIES}

5-bromo-2-fluorobenzaldehydeOxime. $1 \mathrm{H} \mathrm{NMR}(300 \mathrm{MHz}, \mathrm{CDCl} 3): 8.30 \mathrm{~s}, 2 \mathrm{H}(\mathrm{CH}=\mathrm{NOH})$, 7.89 -7.48 d,3H (Ar-H) 13C-NMR (DMSO, ppm): $161.01(\mathrm{C}=\mathrm{N}-\mathrm{OH}), 133.30-129.70(\mathrm{Ar}-\mathrm{C})$.

[5-bromo-2-fluorobenzaldehydeOxime)Cu]: 1H-NMR (DMSO, ppm): $11.78 \mathrm{~s}, 1 \mathrm{H}(\mathrm{O} \ldots \mathrm{H})$, $8.13 \mathrm{~s}, 1 \mathrm{H}(\mathrm{CH}=\mathrm{NOH}), 7.8 \mathrm{~d}, 3 \mathrm{H}(\mathrm{Ar}-\mathrm{H})$. 13C-NMR (DMSO, ppm): $140.84(\mathrm{C}=\mathrm{N}-\mathrm{OH})$, 133.67-129.01 (Ar-C).

[5-bromo-2-fluorobenzaldehydeOxime)Zn]: 1H-NMR (DMSO, ppm): $11.82 \mathrm{~s}, 1 \mathrm{H}(\mathrm{O} \ldots \mathrm{H})$, $8.15 \mathrm{~s}, 1 \mathrm{H}(\mathrm{CH}=\mathrm{NOH}), 7.84-7.60 \mathrm{~d}, 3 \mathrm{H}(\mathrm{Ar}-\mathrm{H})$. 13C-NMR (DMSO, ppm): $160.04(\mathrm{C}=\mathrm{N}-$ $\mathrm{OH}), 140.83-133.53$ (Ar-C).

[5-bromo-2-fluorobenzaldehydeOxime)Hg]: 1H-NMR (DMSO, ppm): $11.81 \mathrm{~s}, 1 \mathrm{H}(\mathrm{O} \ldots \mathrm{H})$, $8.17 \mathrm{~s}, 1 \mathrm{H}(\mathrm{CH}=\mathrm{NOH}), 7.8 \mathrm{~d}, 3 \mathrm{H}(\mathrm{Ar}-\mathrm{H}) .13 \mathrm{C}-\mathrm{NMR}$ (DMSO, ppm): $140.84(\mathrm{C}=\mathrm{N}-\mathrm{OH})$, 133.62-129.05 (Ar-C). 
The ${ }^{1} \mathrm{H}-\mathrm{NMR}$ spectra has provide the evidence for the structural characteristics of the oxime ligand.

The ${ }^{1} \mathrm{H}-\mathrm{NMR}$ chemical shift at $8.30 \mathrm{ppm}$ with sharp singlet had indicated the presence of aldehydic proton, which is lower field shifted to $8.13 \mathrm{ppm}$ in the spectrum of the aldoxime ligand through the oximation reaction ${ }^{17}$.

The spectrum of the 5-bromo-2-fluorobenzaldehydeoximeligand exhibited multiplet signals at 7.45-7.60 ppm due to aromaticprotons ${ }^{18}$.

In addition, the spectrum of the ligand 5-bromo-2-fluorobenzaldehydeoxime showed a singlet signal at $10.20 \mathrm{ppm}$ due to the hydrogen of the $-\mathrm{OH}$ group. The ${ }^{1} \mathrm{H}-\mathrm{NMR}$ spectrum of the ligand exhibited a signal at $14.20 \mathrm{ppm}$, which can be attributed to the hydrogen bonded $\mathrm{OH}$ proton of the hydroxyl imino group.

The coordination of the ligands have been further substantiated by the $1 \mathrm{H}$ NMR spectra of the ligands and some of their complexes with $\mathrm{Cu}(\mathrm{II}), \mathrm{Zn}$ (II) and $\mathrm{Hg}$ (II).

In the spectra of the ligands, the protons observed at $(\delta 8.0-8.1 \mathrm{ppm})$ shift downfield in the spectra of the complexes $(\delta 8.5-8.6 \mathrm{ppm})$, this deshielding is possibly due to the donation of the lone pair of electrons by the azomethine nitrogen to the metal atom resulting in formation of a coordination bond.

\section{ANTIMICROBIAL ASSAY}

Synthesized compounds were tested for inhibition against the human pathogenic bacteria and fungi.

Microbial assay were carried out by disc diffusion technique followed by Kelman et al., 2001. Pathogenic bacterial strains were inoculated in sterile nutrient broth and incubated at $37^{\circ} \mathrm{C}$ for $24 \mathrm{~h}$.

Pathogens were swabbed on the surface of the Muller Hinton Agar plates and discs (Whatmann No.1 filter paper with $9 \mathrm{~mm}$ diameter) were impregnated with the $50 \mu \mathrm{l}$ of synthesized compound on the surface.

In vitro antifungal activity of synthesized compound was determined against CzapexDox Agar, inoculums of $24 \mathrm{~h}$ old culture of Aspergillus flavus well drained spores were distributed uniformly on the surface of the agar plates with the help of sterile cotton swab.

Fungalstrain, Mucor sp. was inoculated by taking a piece of fungal colony using a sterile cotton swab and gently swabbed on the surface of the medium. Control discs were placed with antibiotic and solvents to asses the effect of antibiotic and solvents on pathogens. The plates were incubated at $37^{\circ} \mathrm{C}$ for $24 \mathrm{~h}$ and the antimicrobial activity was measured based on the inhibition zone around the disc impregnated with synthesized compounds.

The zone of inhibition in different bacterial strains against synthesized compoundss shown in Table 1.

Among the various bacterial strains maximum zone of inhibition $(13 \mathrm{~mm})$ was recorded in Salmonella typhi strain and minimum zone of inhibition $(2 \mathrm{~mm})$ was observed in Vibrio cholera, Streptococcus pneumonia and Staphylococcus aureus strains.

The antifungal activity of the synthesized compounds shows maximum activity (12 $\mathrm{mm}$ ) in Mucor sp. 
Table 4. Antimicrobial activity of synthesized compoundsagainst human pathogens

\begin{tabular}{|c|c|c|c|c|c|}
\hline S. No. & Human Pathogens & LIGAND & Cu(II) & Zn(II) & Hg(II) \\
\hline 1 & Pseudomonas aeruginos & + & + & ++ & ++ \\
\hline 2 & Vibrio cholera & + & + & + & + \\
\hline 3 & Vibrio parahaemolyticus & + & + & + & + \\
\hline 4 & Staphylococcus aureus & + & - & ++ & + \\
\hline 5 & Escherichia coli & + & ++ & + & + \\
\hline 6 & Streptococcus pneumonia & + & + & + & - \\
\hline 7 & Salmonella typhi & + & + & + & + \\
\hline 8 & Klebsiella pneumonia & + & ++ & + & ++ \\
\hline 9 & Aspergillus flavus & + & + & + & + \\
\hline 10 & \multicolumn{2}{|c|}{ Mucor sp } & + & + & + \\
\hline 11 & Ampicillin standard & +++ & + & + \\
\hline
\end{tabular}

\section{CONCLUSIONS}

In this paper, we have explored the synthesis and coordination chemistry of some mononuclear complexes derived from the di substituted benzaldehydeoxime ligand. Its containing various transition metal complexes such us $\mathrm{Ni}(\mathrm{II}), \mathrm{Cu}$ (II) and $\mathrm{Co}$ (II) were synthesized and evaluated, their antimicrobial activities using disk diffusion method against bacteria and fungi were determinated. According to the UV-Vis, IR and NMR data of the azomethine linked oxime ligand, the complexes coordinated to the metal ion through the oxime nitrogen and oxygen atom of the hydroxyl group in substituted benzaldehyde. Based on the obtained results, the structure of the coordination compound sunder investigation can be formulated as in Scheme II.

\section{References}

[1]. Desai J. J., Desai P. G., Mehta A. G., Asian J Chem. 11 (1999) 519.

[2]. Desai J. J., Desai P. G., Mehta A. G., Asian J Chem. 12 (2000) 1067.

[3]. Hania M. M., Asian J Chem. 14 (2002) 1074. 
[4]. Rai B. K., Asian J Chem. 14 (2002) 1595.

[5]. Rai B. K., Asian J Chem. 14 (2002) 312.

[6]. Hania M. M., Asian J Chem. 17 (2005) 439.

[7]. Dobeck A. S., Klayman D., Antimicrob Agents Chemother. 18 (1980) 27.

[8]. Wagner W. H., Winkelman E., Arzneim Forschi 22 (1972) 1713.

[9]. Hania M. M., Asian J Chem. 17 (2007) 439.

[10]. Morrison N. E., Collins F. M, Int J Leprosy 49 (1981) 180.

[11]. Jones D. H., Slack R., Squires S., J Med Chem. 2 (1965) 676.

[12]. Klayman D. L., Joseph F., J Med Chem., 22 (1979) 855.

[13] Bauer D. J., Vincent L. S., Kempe C. H., Dowine A. W., Lancet, 2 (1963) 494.

[14]. Petering H. G., Buskik H. H., Underwood G. E., Cancer Res. 64 ( 1963$) 367$.

[15]. K. Krishnankutty, M. B. Ummathur, P. Ummer, J. Serb. Chem. Soc. 74 (2009) 1273.

[16]. Rana A. K., Shah J. R., Indian J Chem. 20A (1981) 142.

[17]. M. Kurtoğlu, E. Ispir, N. Kurtoğlu, S. Serin, Dyes Pigm. 77 (2008) 75.

[18]. R. M. Silverstein, G. C. Bassler, T. C. Morrill., Spectrometric Identification of Organic Compounds, 5th ed., Wiley, New York, 1991. 